\title{
THE EFFECTS OF HEATING ANTI-HUMAN GLOBULIN SERA
}

\author{
BY \\ DENISE A. HUNTER AND ANN R. THOMAS \\ From the Medical Research Council's Blood Transfusion Research Unit, Postgraduate Medical School, London
}

(RECEIVED FOR PUBLICATION JULY 17, 1956)

Anti-human globulin sera produced in rabbits invariably contain hetero-agglutinins, reacting with normal human red cells. These hetero-agglutinins are usually weak, so that if the rabbit serum is diluted at least ten-fold they may cause no interference. Anti-human globulin sera are in fact most often used at dilutions greater than 1 in 10 , since at such dilutions they react best with red cells sensitized with $\mathrm{Rh}$ antibody. However, red cells sensitized with some other blood group antibodies, such as anti-Le $\mathrm{L}^{\mathrm{a}}$, often react best with undiluted rather than diluted antiglobulin serum. For such cases the antiglobulin serum must be freed from hetero-agglutinins. This is usually done by absorbing the serum with cells of groups $\mathrm{A} ; \mathrm{B}$, and $\mathrm{O}$, a time-consuming process, since the cells must first be freed from traces of plasma (globulin) by repeated washing in large volumes of saline.

An attractive alternative method was suggested by van Loghem (1950), who showed that the heteroagglutinins could be destroyed by heating the serum for one to two hours at $63^{\circ} \mathrm{C}$. Menolasino and Davidsohn (1954) found that a shorter period at a higher temperature $\left(70^{\circ} \mathrm{C}\right.$. for half an hour) was also effective. In both cases the anti-human globulin serum was found to react well with cells sensitized with anti-Rh.

It was thought worth while to compare the effects of heating at $63^{\circ} \mathrm{C}$. and at $70^{\circ} \mathrm{C}$. on unwanted agglutinins, and to test the heated sera for their ability to react with cells sensitized with " nongamma globulins", (Cutbush, Crawford, and Mollison, 1955).

\section{Methods}

Antiglobulin Sera.-Eight different antiglobulin sera were prepared in rabbits. Rabbit I was given intramuscular injections of alum-precipitated serum, followed at monthly intervals by intravenous injections of whole human serum.

Rabbits II, III, IV, V, VI, and VII were given at least two intraperitoneal injections of $0.3 \mathrm{ml}$. of a solution containing $1 \%$ gamma globulin.
Rabbit VIII received injections of whole human serum, followed by injections of gamma globulin.

Tests for the Presence of Hetero-agglutinins. - Each serum was diluted $1 / 2$ and one drop of this mixed with a drop of a $15 \%$ suspension of unsensitized group $\mathrm{O}$ cells. The mixture was rocked on an opal glass tile over a light and watched for six minutes. The sera were also tested with unsensitized group $A_{1}$ and $B$ cells.

Absorption of Hetero-agglutinins.-The sera were inactivated by heating at $56^{\circ} \mathrm{C}$. for 30 minutes. Red cells of groups $\mathrm{A}, \mathrm{B}$, and $\mathrm{O}$ were washed 10 times in large volumes of a $1 \%$ saline solution. One volume of packed cells was mixed with one volume of antiglobulin serum. After 15 minutes at room temperature the mixture was centrifuged for 15 minutes. The supernatant serum was removed and the procedure was repeated.

Removal of Hetero-agglutinins by Heat.-Each serum was diluted $1 / 2$ in saline and samples of each serum were heated at $63^{\circ} \mathrm{C}$. for 30 minutes, one hour, and two hours, and at $70^{\circ} \mathrm{C}$. for five minutes, 15 minutes, and 30 minutes.

Preparation of Sensitized Cells.-Group O cells were sensitized by incubation at $37^{\circ} \mathrm{C}$. with a serum containing anti-Rh and fresh serum containing anti-Le ${ }^{a}$. "Normal cold "-sensitized cells were prepared by mixing 1 volume of fresh $\mathrm{O}$ cells with 20 volumes of fresh normal human serum; this mixture was placed in an ice-bath for two hours. Sensitized red cells were also obtained from three patients with acquired haemolytic anaemia of the "cold antibody type" (Dacie, 1954, p. 175). All three patients were of group $O$.

\section{Results}

Removal of Hetero-agglutinins.-In most cases the untreated antiglobulin serum reacted more strongly with cells of group A and of group B than with cells of group $O$. The results given in Table I refer to the reactions of mixed $A_{1}, B$, and $O$ cells. Four of the eight sera were free from heteroagglutinins after heating at $63^{\circ} \mathrm{C}$. for 30 minutes; seven of the sera were free from hetero-agglutinins after heating at $70^{\circ} \mathrm{C}$. for five minutes. In six of the eight cases the sera were successfully absorbed by treatment with 2 volumes of packed cells. 
TABLE I

EFFECT OF VARIOUS TREATMENTS ON REACTIONS OF EIGHT ANTI-HUMAN GLOBULIN SERA WITH UNSENSITIZED CELLS OF GROUPS A, B, AND O

\begin{tabular}{|c|c|c|c|c|c|c|c|c|}
\hline \multirow{2}{*}{ Treatment of Serum } & \multicolumn{8}{|c|}{ Antiglobulin Sera } \\
\hline & I & II & III & IV & $\mathrm{V}$ & VI & VII & VIII \\
\hline 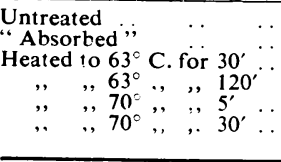 & $\begin{array}{l}+- \\
(-) \\
(-) \\
w \\
-\end{array}$ & $\begin{array}{c}+-+ \\
- \\
+-+ \\
-+ \\
++ \\
(-)\end{array}$ & $\begin{array}{l}++ \\
- \\
(+) \\
- \\
- \\
-\end{array}$ & $\begin{array}{c}+-1 \\
- \\
+- \\
+ \\
- \\
-\end{array}$ & $\begin{array}{l}+ \\
- \\
- \\
- \\
-\end{array}$ & $\begin{array}{l}- \\
- \\
- \\
-\end{array}$ & $\begin{array}{l}I \\
- \\
- \\
- \\
-\end{array}$ & $\begin{array}{l}++ \\
+ \\
- \\
- \\
-\end{array}$ \\
\hline
\end{tabular}

The symbols used in Tables I and III indicate the grade of agglutination.

TABLE II

EFFECT OF HEATING TO $63^{\circ} \mathrm{C}$. AND TO $70^{\circ} \mathrm{C}$. ON REACTIONS OF EIGHT ANTIGLOBULIN SERA WITH LesSENSITIZED CELLS, NORMAL COLD-SENSITIZED CELLS, AND A.H.A. COLD CELLS

\begin{tabular}{|c|c|c|c|c|c|c|c|c|c|c|}
\hline \multirow{2}{*}{$\begin{array}{c}\text { Sensitized } \\
\text { Cells }\end{array}$} & \multirow{2}{*}{\multicolumn{2}{|c|}{ Treatment of Serum }} & \multicolumn{7}{|c|}{ Antiglobulin Sera } & \multirow[b]{2}{*}{ VIII } \\
\hline & & & I & II & III & IV & $\mathrm{V}$ & VI & VII & \\
\hline $\mathrm{Le}^{\mathrm{a}}$ & $\begin{array}{l}\text { Absorbed } 63^{\circ} \text { for } 30^{\prime} \\
\text { Heated to } 60^{\circ},, 5^{\prime} \\
\qquad, \quad, 70^{\circ},\end{array}$ & $\begin{array}{l}\cdots \\
\cdots \\
\cdots\end{array}$ & $\begin{array}{l}+ \\
(-) \\
(-)\end{array}$ & $\begin{array}{c}+ \\
(+) \\
(+)\end{array}$ & + & $\begin{array}{l}+ \\
+ \\
+\end{array}$ & $\begin{array}{r}+ \\
+ \\
+\end{array}$ & + & $\begin{array}{l}+ \\
- \\
\end{array}$ & $\begin{array}{l}+ \\
+ \\
+\end{array}$ \\
\hline Normal cold & $\begin{array}{l}\text { Absorbed } 63^{\circ} \text { for } 30^{\prime} \\
\text { Heated to } 60^{\circ},, 5^{\prime} \\
\qquad,,, 70^{\circ}\end{array}$ & $\begin{array}{l}\cdots \\
\cdots \\
\cdots\end{array}$ & $\begin{array}{l}+ \\
+ \\
+\end{array}$ & + & - & $\begin{array}{l}+ \\
+ \\
+\end{array}$ & $(\bar{i}$ & $(+\overline{+})$ & $\begin{array}{l}- \\
- \\
-\end{array}$ & $\begin{array}{r}+ \\
+\end{array}$ \\
\hline a.h.a. cold & $\begin{array}{l}\text { Absorbed } \\
\text { Heated to } 63 \text { for } 30^{\prime} \\
\qquad, \quad,, 70^{\circ},, 5^{\prime}\end{array}$ & $\begin{array}{l}\cdots \\
\cdots \\
\cdots\end{array}$ & + & $\begin{array}{l}+ \\
\dot{T} \\
(+)\end{array}$ & $\frac{\bar{T}}{(-)}$ & $\begin{array}{l}I \\
I\end{array}$ & $\begin{array}{l}- \\
-\end{array}$ & $\begin{array}{c}+ \\
(-)\end{array}$ & $\begin{array}{c}+ \\
+ \\
(-)\end{array}$ & $\overline{-}$ \\
\hline
\end{tabular}

$+=$ Reaction unaffected; $(+)=$ Reaction weaker ; $-=$ No reaction.

TABLE III

EFFECT OF HEATING TO $63^{\circ} \mathrm{C}$. AND TO $70^{\circ} \mathrm{C}$. ON REACTIONS OF ANTIGLOBULIN SERUM V WITH Rh-SENSITIZED, Le*-SENSITIZED, NORMAL COLD-SENSITIZED, AND A.H.A. COLD CELLS

\begin{tabular}{|c|c|c|c|c|c|c|c|c|}
\hline \multirow{2}{*}{$\begin{array}{l}\text { Sensitized } \\
\text { Cells }\end{array}$} & \multirow{2}{*}{ Treatment of Serum } & \multicolumn{7}{|c|}{ Dilutions of Serum V } \\
\hline & & 12 & 14 & 18 & 116 & 1,32 & 1,64 & 1128 \\
\hline $\mathrm{Rh}$ & 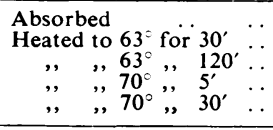 & $\begin{array}{l}I+ \\
I+ \\
I+ \\
+\end{array}$ & $\begin{array}{l}T+ \\
+T \\
T+ \\
T+\end{array}$ & 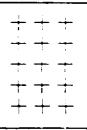 & 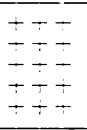 & $\begin{array}{l}F \\
I I \\
I T \\
T-\end{array}$ & $\begin{array}{l} \pm \\
\pm \\
\pm \\
+\end{array}$ & $\begin{array}{l}(+) \\
(+) \\
(+) \\
(+) \\
(+)\end{array}$ \\
\hline $\mathrm{Le}^{\mathrm{a}}$ & 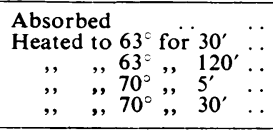 & $\begin{array}{l}T+ \\
I T \\
I T \\
I T \\
I+\end{array}$ & $\begin{array}{l}T+ \\
+T \\
+T \\
++ \\
++\end{array}$ & $\begin{array}{l}+\dot{T} \\
\dot{T} \\
+T \\
+T \\
+T\end{array}$ & $\begin{array}{l}I+ \\
I T \\
I T \\
I T \\
I T\end{array}$ & $\begin{array}{l}\overline{-} \\
\bar{Y} \\
\bar{Y} \\
\bar{T}\end{array}$ & $\begin{array}{l}\bar{I} \\
\dot{+} \\
(\overline{+})\end{array}$ & $\begin{array}{l}(+) \\
(+) \\
(+) \\
(+) \\
(+)\end{array}$ \\
\hline Normal cold & 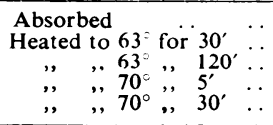 & 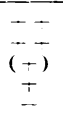 & $\begin{array}{l}+ \\
+ \\
w \\
+ \\
+\end{array}$ & $\begin{array}{l}\bar{z} \\
\bar{w} \\
\overline{-}\end{array}$ & $\begin{array}{l}- \\
(-) \\
= \\
-\end{array}$ & $\begin{array}{l}w \\
- \\
- \\
- \\
-\end{array}$ & $\begin{array}{l}\overline{-} \\
\overline{-} \\
\overline{-}\end{array}$ & $\begin{array}{l}- \\
\overline{-} \\
\overline{-} \\
-\end{array}$ \\
\hline a.h.a. cold & 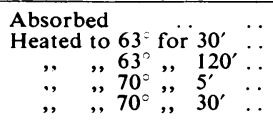 & $\begin{array}{l}+\bar{I} \\
\dot{I} \\
+T \\
+\end{array}$ & $\begin{array}{l}++ \\
+T \\
+t \\
++ \\
\text { w }\end{array}$ & $\begin{array}{l}++ \\
+T \\
+ \\
++ \\
-\end{array}$ & $\begin{array}{l}++ \\
+\div \\
+ \\
++ \\
-\end{array}$ & $\begin{array}{l}= \\
(\overline{-}) \\
I\end{array}$ & $\begin{array}{l}(+) \\
(+) \\
(+) \\
(+)\end{array}$ & $\begin{array}{l}\overline{-} \\
\bar{z} \\
\overline{-} \\
-\end{array}$ \\
\hline
\end{tabular}

Reactions with Sensitized Cells.-Table II shows the reactions of $\mathrm{Le}^{\mathrm{a}}$-sensitized cells, of normal cold-sensitized cells, and of cells from a patient with acquired haemolytic anaemia (a.h.a. cold) with eight anti-human globulin sera after absorption and afier heating. In each case the "treated" sera gave no reaction with unsensitized cells of group $\mathrm{O}$.

The reactions, with sensitized cells, of sera IV and VIII are unaffected by heating to $63^{\circ} \mathrm{C}$. for 30 minutes, or to $70^{\circ} \mathrm{C}$. for five minutes. The remaining six sera react less well after heating: 
sera I, II, III, VI, and VII react less well with $\mathrm{Le}^{\mathrm{a}}$-sensitized cells; sera $\mathrm{V}$ and VI react less well with " normal cold" sensitized cells; and sera II, III, VI, and VII react less well with "a.h.a. cold", sensitized cells.

Table III shows, in more detail, the effects of heating one serum (serum $\mathrm{V}$ ) at $63^{\circ} \mathrm{C}$. for 30 minutes and 120 minutes, and at $70^{\circ} \mathrm{C}$. for five minutes and 30 minutes. This serum reacted very weakly with a.h.a. cold cells and failed to react with normal cold-sensitized cells after heating at $70^{\circ} \mathrm{C}$. for 30 minutes. Heating at $63^{\circ} \mathrm{C}$. for 30 minutes did not affect the serum's ability to react with these cells.

\section{Recommendations}

On the basis of the limited testing of eight antiglobulin sera it is recommended that a sample of each serum (diluted $1 / 2$ ) should be heated to $63^{\circ} \mathrm{C}$. for 30 minutes; if this treatment fails to remove the hetero-agglutinins, the serum should be absorbed with washed cells of groups A, B, and $O$.

If the serum is to be used only for detecting $\mathrm{Rh}$ antibody, the hetero-agglutinins can be removed by heating to higher temperatures $\left(70^{\circ} \mathrm{C}\right.$.), or for a longer period at $63^{\circ} \mathrm{C}$. However, this treatment may impair the serum's ability to react with cells sensitized with " non-gamma" globulins.

\section{Summary}

Eight anti-human globulin sera were heated at $63^{\circ} \mathrm{C}$. and at $70^{\circ} \mathrm{C}$. for short periods (five minutes to two hours). The effect of this treatment on hetero-agglutinins, and on the ability of the serum to react with four types of sensitized cells, was investigated.

We should like to thank Miss Marie Cutbush and Dr. P. L. Mollison for suggesting this work, and for helping to prepare this paper for publication.

\section{REFERENCES}

Cutbush, M., Crawford, H., and Molliscn, P. L. (1955). Brit. J. Haemat., 1, 410.

Dacie, J. V. (1954). The Haemolytic Anaemics, Congenital and Acquired. Churchill, Lcndon.

Loghem, J. J. van (1950). Maandschr. Kindergeneesk., 18, 115.

Menolasino, N. J., and Davidsohn, I. (1954). Amer. J. clin. Path., 24, 1205. 